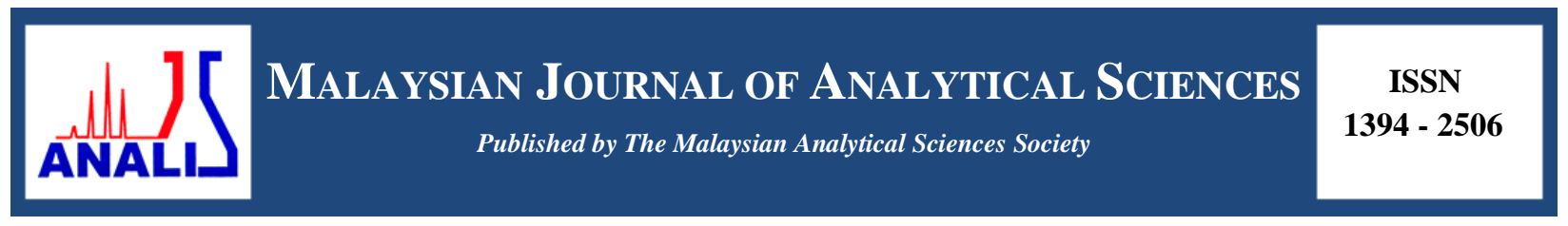

\title{
QUALITY PARAMETERS OF Curcuma longa L. EXTRACTS BY SUPERCRITICAL FLUID EXTRACTION (SFE) AND ULTRASONIC ASSISTED EXTRACTION (UAE)
}

\author{
(Parameter Kualiti Ekstrak Curcuma longa L. daripada Pengekstrakan Cecair Supergenting \\ (SFE) dan Pengekstrakan Ultrasonik Berbantu (UAE)) \\ Zaibunnisa Abdul Haiyee ${ }^{1}$, Siti Hafsah Mohd Shah ${ }^{1}$, Khudzir Ismail $^{1}$, Nooraain Hashim ${ }^{1}$, \\ Wan Iryani Wan Ismail ${ }^{2}$ \\ ${ }^{1}$ Faculty of Applied Sciences, \\ Universiti Teknologi MARA, 40450 Shah Alam, Selangor, Malaysia \\ ${ }^{2}$ Faculty of Pharmacy, \\ Universiti Teknologi MARA, 42300 Puncak Alam, Selangor, Malaysia \\ *Corresponding author: nisha@salam.uitm.edu.my
}

Received: 24 February 2015; Accepted: 27 October 2015

\begin{abstract}
Turmeric is one of the prominently use herbal plants due to its diverse beneficial effects especially in Indian medicine. The rhizome part of the turmeric contains valuable compounds which have been said to owe its antimicrobial effects, anti-cancer, anti-inflammatory and enhance wound healing. Due to its short-life span and perishable properties, the conversion of the rhizome into turmeric extract is desirable. Several methods have been used for extraction such as Soxhlet extraction and pressurized liquid extraction (PLE). However, these techniques are tedious, laborious, time consuming and involves the usage of toxic organic solvent, of which safeness of the end product is doubtful. In this study, a rapid, reliable and green extraction method of supercritical fluid extraction (SFE) and ultrasonic assisted extraction (UAE) were used. SFE without modifier has resulted in $0.0006 \mathrm{mg} / 100 \mathrm{~g}$ of curcuminoids concentration and $5.62 \%$ of yield (dry weight basis). UAE using ethanol was able to produce significantly the highest yield $(6.40 \%$, dry weight basis) and the highest curcuminoids concentration $(0.1020 \mathrm{mg} / 100 \mathrm{~g})$. However, SFE was able to produce extract that contain significantly higher major volatile compounds; tumerone, ar-turmerone and curlone. Therefore, this study proves that both extraction methods were able to produce high quality turmeric extract.
\end{abstract}

Keywords: Supercritical fluid extraction, Ultrasonic assisted extraction, percentage yield, curcuminoids, volatile compounds

\begin{abstract}
Abstrak
Kunyit merupakan tumbuhan herba yang terkenal disebabkan kebaikannya yang pelbagai terutamanya dalam perubatan masyarakat India. Bahagian rizom kunyit mengandungi sebatian berkhasiat yang dipercayai mempunyai kesan antimikrobial, anti-kanser, anti-keradangan dan juga mempercepatkan kadar penyembuhan luka. Disebabkan kitar hidup yang singkat dan ciri mudah rosak yang terdapat pada kunyit, maka penukaran rizom kunyit kepada ekstrak kunyit adalah amat wajar. Beberapa kaedah pengekstrakan telah digunakan seperti pengekstrakan Soxhlet dan pengekstrakan cecair bertekanan (PLE). Bagaimanapun, kaedah-kaedah tersebut amat rumit, sukar, mengambil masa yang lama serta melibatkan penggunaan pelarut organik bertoksik yang menyebabkan keraguan terhadap tahap keselamatan produk iaitu ekstrak kunyit. Di dalam kajian ini, kaedah pengekstrakan yang pantas, dipercayai serta mesra alam iaitu pengekstrakan cecair supergenting (SFE) dan pengekstrakan ultrasonik berbantu (UAE) telah digunakan. SFE tanpa bahan pengubahsuai telah menghasilkan $0.0006 \mathrm{mg} / 100 \mathrm{~g}$ kepekatan kurkuminoids dan 5.62 \% hasil ekstrak kunyit (berdasarkan berat kering). UAE menggunakan etanol telah menghasilkan hasil ekstrak yang ketara tinggi $(6.40 \%$, berdasarkan berat kering) dan nilai kepekatan kurkuminoids tertinggi iaitu $0.1020 \mathrm{mg} / 100 \mathrm{~g}$. Walaubagaimanapun, SFE telah menghasilkan ekstrak yang mengandungi sebatian meruap yang
\end{abstract}


signifikan tingginya iaitu tumerone, ar-turmerone dan curlone. Maka, kajian ini membuktikan bahawa kedua-dua kaedah berupaya menghasilkan produk ekstrak kunyit yang berkualiti tinggi.

Kata kunci: Pengekstrakan cecair supergenting, Pengekstrakan ultrasonik berbantu, peratusan hasil, kurkuminoids, sebatian meruap

\section{Introduction}

Turmeric (Curcuma longa L.) is an economically important plant for the production of turmeric based products. It is well known worldwide as one of the major source of drug both in modern and traditional system of medicine for possessing number of biomolecules credited with myriad of therapeutic activities [1]. The extract of turmeric rhizome consisting of a light (volatile oil) fraction and a heavy (non volatile) fraction of yellowish-brown colour [2]. Ar-tumerone is the marker compound in turmeric oil which contributes to its camphory note $[3,4]$ while curcumin, demethoxycurcumin and bisdemethoxycurcumin and the non-volatile compounds of turmeric acts as colouring agent [2].

Currently, there are several extraction techniques have been used to extract turmeric oils and bioactive components from plant such as Soxhlet distillation, hydrodistillation, solid-liquid extraction and blending. Some of the disadvantages of using these techniques are long extraction time, large consumption of toxic organic solvents and low percentage of oil yield. Supercritical fluid extraction (SFE) and ultrasonic assisted extraction (UAE) are recent techniques that can overcome the shortcomings of traditional methods. SFE has advantages such as environmental friendly as it does not use toxic organic solvent, able to select thermally labile compounds under mild conditions and has a shorter time. Other than SFE, UAE is also one of the alternative methods to replace conventional extraction processes [5]. In most previous literatures, UAE has been known as a tool that assists in the extraction of medicinal compounds or different vegetal materials [6]. It has many advantages such as it can improve extraction efficiency, extraction rate and reduce extraction temperature [7]. UAE also utilizes the ultrasound during extraction that can disrupt the biological cell wall, and thus facilitating the release of contents [8].

In this present work, the efficiency of SFE and UAE techniques on the extraction of Curcuma longa L. extract been compared based on the percentage yield, curcuminoids concentration and volatile components.

\section{Chemicals and raw materials}

\section{Materials and Methods}

Ethanol used for GC-MS and UV-Visible spectrophotometer was of analytical grade and purchased from Merck Sdn. Bhd (Selangor, Malaysia). Fresh turmeric rhizomes (Curcuma longa L.) were bought from a local cultivator in Selangor, Malaysia.

\section{Preparation of dried turmeric powder}

Fresh turmeric rhizomes were cleaned with water and sliced about $3 \mathrm{~mm}$ thick and air-dried at room temperature until the moisture content reached to $10-15 \%$ as reported by Zaibunnisa et al. [9]. Samples were then ground and sieved to $2 \mathrm{~mm}$ size and were put into sealed plastic bags at chilled temperature until further analysis.

\section{Determination of moisture content}

The moisture content of dried turmeric rhizome was determined using AOAC method [10].

\section{Extraction methods}

\section{Supercritical Fluid Extraction (SFE)}

Extractions were carried out using supercritical carbon dioxide $\left(\mathrm{SC}-\mathrm{CO}_{2}\right)$ laboratory scale extraction system $(\mathrm{TST}$, Ltd., Taiwan). Turmeric sample was extracted with supercritical carbon dioxide in a continuous-flow extractor. For the first cycle, sample $(211 \mathrm{~g})$ of the dried turmeric powder was accurately weighed and packed inside $1 \mathrm{~L}$ extraction vessel and fixed into extraction oven. Incoming and outgoing tubes were attached at the bottom and upper part of the vessel, respectively. Liquid $\mathrm{CO}_{2}$ from the cylinder was passed, delivered and compressed to 22.5 Mpa by air compressor and heated up to the supercritical condition. For the second cycle, similar process was done, but, for the second cycle, organic modifier (ethanol) was introduced into the system by mixing 211 grams of sample 
with $50 \mathrm{~mL}$ of ethanol before putting it inside the vessel. Operating temperature was set to $40{ }^{\circ} \mathrm{C}$ for each cycles. The temperature was measured using a thermocouple device. Both extraction cycles; with and without modifier, were conducted at similar pressure and temperature. The extract was collected in a glass vial and kept for further analysis.

\section{Ultrasonic Assisted Extraction (UAE)}

Ultrasonic assisted extraction was performed in an ultrasonic water bath with temperature control. Dried turmeric powder (50 grams) were placed in two glass beaker and mixed with $400 \mathrm{~mL}$ water and ethanol, respectively. Samples were exposed to ultrasonic waves for pre-defined time periods ( 15 minutes) consecutively at $40{ }^{\circ} \mathrm{C}$ with frequency about $40 \mathrm{kHz}$ until extraction fully completed. The extracts were collected, filtered and dried using rotary evaporator for further analysis.

\section{Extraction yield}

The weight of the extracts were obtained and used for the calculations of the percentage yield as carried out by Zaibunnisa et al. [9].

\section{Curcuminoids concentration}

The curcuminoids concentration in the turmeric extract was determined by spectrophotometric method according to Haiyee et al. [11]. Turmeric extract $(0.002 \mathrm{~g})$ was dissolved with $10 \mathrm{~mL}$ of $95 \%$ ethanol. The absorbance was measured at $425 \mathrm{~nm}$ using $95 \%$ ethanol as blank. Curcuminoids concentration in the sample was quantified using standard calibration curve of pure curcumin, concentration of $0.25,0.50,0.75,1.00$ and $1.25 \mathrm{ppm}$. Triplicate analysis were carried out for each treatment.

\section{Volatile compounds}

The volatiles were analyzed using Agilent Technologies 6890N Network GC system equipped with an Agilent Technologies 5973 Inert Mass Selective Detector and Agilent 7683 Series Injector [9]. A HP-5MS column was used. GC-MS detection was done using an electroionization system with ionization energy of $70 \mathrm{eV}$ in the 50 to 550 a.m.u. mass range. Column temperature was increased from $60{ }^{\circ} \mathrm{C}$ to $325^{\circ} \mathrm{C}$ at the rate of $10{ }^{\circ} \mathrm{C} / \mathrm{min}$. Initial and final time were 6 minutes and 10 minutes, respectively. Helium was used as the carrier gas, at a flow rate of 1.0 $\mathrm{mL} / \mathrm{min}$ in splitless mode. Identification of the compounds was done by comparing their relative retention indices and mass spectral fragmentation pattern with those of NIST data inbuilt library provided along with instrument [9].

\section{Extraction yield}

\section{Results and Discussion}

Percentage yield of Curcuma longa L. extract obtained from different extraction methods are shown in Table 1 below.

Table 1. Percentage yields of turmeric extract obtained from different extraction techniques

\begin{tabular}{lcc}
\hline Extraction techniques & \multicolumn{2}{c}{ Yield (\%) } \\
\hline Ultrasonic assisted extraction & Ethanol & Water \\
& $6.40 \pm 0.80^{\mathrm{a}}$ & $4.72 \pm 0.66^{\mathrm{b}}$ \\
\hline Supercritical fluid extraction & Without modifier & With modifier \\
& $5.62 \pm 0.19^{\mathrm{a}}$ & $5.21 \pm 0.46^{\mathrm{a}}$ \\
\hline
\end{tabular}

Data shown as mean \pm S.D. from triplicate determinations, Superscript ${ }^{\mathrm{a} b}$ within row showed significant differences at $(p<0.05)$

Generally, extraction using ultrasonic assisted extraction (UAE) were able to produce higher yield compared with supercritical fluid extraction (SFE). Ethanol and water have been chosen as the extraction solvents for ultrasonic study due to the fact that they are safer in handling as compared to other organic solvents like methanol and acetone. 
For ultrasonic assisted extraction, with ethanol resulted in significantly higher yield compared to with water. This is due to the function of ethanol that acts as a liquid which received the ultrasonic waves with high intensity and forms bubbles or cavities [7]. This acoustic cavitation, when triggered close to solid surfaces like dried turmeric powder will make the cavity collapse and thus produces high-speed jets of liquid that impact strongly to the solid surface [7] of dried turmeric powder. Eventually, it will lead to pitting and errosion [7] of the dried turmeric surface and easier for the materials being extracted out from the plant matrices. However, the yield obtained from UAE with water was lower which might be due to insolubility of some turmeric compounds in water.

Since SFE only extracting the volatiles, the yield obtained was significantly lower than UAE. This probably due to extraction can be done without the usage of modifier as the carbon dioxide used in the SFE itself will be able to extract out all compounds at supercritical point whereby the temperature and pressure set has reaches the critical point. This was also supported by previous research done by Chang et al. [5], which reported that the use of supercritical carbon dioxide was possible without the addition of co-solvents. Carbon dioxide have been widely used as extracting solvent for SFE as it is non-toxic, available abundantly, non-explosive, can be removed easily from the final extract without leaving a solvent residue [7] and the most important is the low viscosity of carbon dioxide enables it to penetrate into the matrix of the analyte to reach the material being extracted and extract out the material selectively [7]. Additionally, Daneshvand et al. [7] reported that the most effective factors for SFE were pressure and extraction time. The addition of modifier in SFE method did not have an apparent effect to the process since the result showed only slight differences between SFE, with or without modifier. The volume of modifier added to the dried sample might be too little for the modifier to aid in the extraction process. Chang et al. [5] supported this claimed by stated that larger solvent volume can dissolve target components more effectively and thus increase the extraction yield.

\section{Curcuminoids content}

The curcuminoids concentration was higher in UAE in comparison to SFE as shown in Table 2.

Table 2. Curcuminoids concentrations $(\mathrm{mg} / 100 \mathrm{~g})$ in the extracts obtained from SFE and UAE

\begin{tabular}{llc}
\hline Extraction techniques & \multicolumn{2}{c}{ Curcuminoids concentration $(\mathbf{m g} / \mathbf{1 0 0 g})$} \\
\hline Ultrasonic assisted extraction & Ethanol & Water \\
& $0.1020 \pm 0.0013^{\mathrm{a}}$ & $0.0014 \pm 0.0012^{\mathrm{b}}$ \\
\hline Supercritical fluid extraction & Without modifier $^{\mathrm{a}}$ & With modifier \\
& $0.0006 \pm 0.0002^{\mathrm{a}}$ & $0.0005 \pm 0.0002^{\mathrm{a}}$ \\
\hline
\end{tabular}

Data shown as mean \pm S.D. from triplicate determinations, All values were standardised to $100 \mathrm{~g}$ of turmeric extract, Superscript ${ }^{\mathrm{ab}}$ within row showed significant differences at $(p<0.05)$

Extraction using UAE has affected to the high concentration of curcuminoids since the fascinating role of UAE is it can avoids degradation of bioactive compounds by quenching of radical in aqueous system and also its ability to achieve targeted hydroxylation of polyphenolics like curcuminoids by potential use of the radical sonochemistry [12]. Results also indicated that curcuminoids concentration is the highest when extracted using UAE with ethanol which was $0.1020 \mathrm{mg} / 100 \mathrm{~g}$. These results correlate well with the findings by Wakte et al. [13] and $\mathrm{Li}$ et al. [14] which reported that ethanol gave the highest curcuminoids content among different extraction solvents as more compounds will be dissolved in a polar organic solvent.

Carbon dioxide, the non-polar extracting solvent for SFE causes curcuminoids to only slightly soluble in it. The non-polarity and poor solvation power of SFE- $\mathrm{CO}_{2}$ causes the failure to quantitate extraction of polar analytes from solid matrices [7]. Although SFE can alter carbon dioxide properties to behave either as a polar or non-polar solvent depending on pressure and temperature employed [7], by subjecting it to the supercritical fluid state and extract certain classes of compounds easily [15], however, it can be concluded that the temperature and pressure used in this study might be not sufficient enough to fully extracted the targeted curcuminoids based on the result presented. 
According to Herrero et al., [16], the solubility of target compounds in supercritical fluid is strongly influenced by the properties of solvent such as density whereby the properties of solvent are greatly influenced by pressure and temperature.

\section{Volatile compounds composition}

Traditionally, volatile compounds of turmeric extract were obtained by hydrodistillation techniques which require long extraction times and causes heat-sensitive volatile compounds easily be destroyed [17]. While solvent extraction of plant materials causes safety hazards in term of the toxic solvent residue in the extract and also may lead to oxidation of aroma of the volatile compounds, especially in the presence of air [17].

The chemical components present in the turmeric extract were identified and presented in Table 3 , according to their order of elution from a HP-5MS column. Compounds identification was based on NIST library.

Table 3. Volatile compounds of Curcuma longa L. identified from turmeric extract

\begin{tabular}{|c|c|c|c|c|}
\hline \multirow{3}{*}{ Volatile compounds } & \multicolumn{4}{|c|}{ Extraction techniques } \\
\hline & SFE (modifier) & SFE & UAE (Ethanol) & UAE (Water) \\
\hline & \multicolumn{4}{|c|}{ Relative proportion (area \%) } \\
\hline$\beta$-cymene & 0.58 & n.d. & n.d. & n.d. \\
\hline$\beta$-caryophyllene & n.d. & 0.23 & n.d. & n.d. \\
\hline ar-curcumene & 0.70 & 0.55 & 0.33 & n.d. \\
\hline$\alpha$-zingiberene & 1.15 & 2.09 & 1.26 & n.d. \\
\hline ar-turmerone & 21.50 & 10.84 & 6.84 & n.d. \\
\hline Turmerone & 36.14 & 45.68 & 33.87 & n.d. \\
\hline Curlone & 22.30 & 21.27 & 13.92 & n.d. \\
\hline Cuparene & n.d. & 0.55 & n.d. & n.d. \\
\hline$\beta$-bisabolane & 0.21 & 0.28 & 0.17 & n.d. \\
\hline$\beta$-sesquiphellandrene & 1.38 & 1.74 & 1.01 & n.d. \\
\hline$\beta$-farnesene & 0.60 & 1.74 & n.d. & n.d. \\
\hline
\end{tabular}

n.d. $=$ not-detected

Ten compounds were identified in turmeric extract obtained from SFE, nine compounds for SFE with modifier and seven compounds for UAE with ethanol while no compound was detected for UAE with water. Major compounds found using those techniques were ar-turmerone, turmerone and curlone, while the minor compounds presented using those methods were $\alpha$-zingiberene, $\beta$-sesquiphellandrene, ar-curcumene and $\beta$-bisabolane, except for SFE with and without modifier, of which $\beta$-farnesene was also detected. In addition, $\beta$-cymene was also detected in the extract of SFE with modifier.

The result for this current studies is in accordance with the result obtained from Singh et al. [18] which studied the chemical compositions of four different species of turmeric and they found out that the rhizome of $C$. longa contain mostly sesquiterpinoids and its major constituents are ar-turmerone, $\beta$ - bisabolene, ar-turmerol, zingiberene, $\beta$ caryophyllene while 1,8-cineole was not present. Some volatile compounds such as 1,8 -cineole was not present in the extract and this might be due to its low boiling point as well as high volatility characteristics which resulted in their loss during sample preparation like cutting and grinding steps [19] and post-treatment of the extract such as solvent removal using rotary evaporator. Though the major compounds found were similar among them, the composition of each volatile compound was differed based on the percentage area. This is in agreement with the report from $\mathrm{Li}$ et al. [14], which stated that different extraction methods gives variation in the contents of volatile compounds. 
Most of the compounds for SFE extract show higher percentage area composition than SFE with modifier extract, for instance, SFE contains $45.68 \%$ of turmerone while SFE with modifier extract contains only $36.14 \%$ of turmerone. For UAE technique, only UAE with ethanol reported the presence of volatile compounds but in small percentage area as compared to SFE extract. It is clearly show that SFE will be able to produce more volatile compounds with high percentage area. Extraction techniques that uses organic solvent like ethanol contains lacks of volatile compounds composition due to the losses of the compounds during evaporation process of the solvents [3]. UAE using water as extracting solvent shows the absence of volatile compound since removing of water by evaporation takes longer time and requires high boiling point of water which leads to the losses of more volatile compounds than UAE with ethanol because ethanol was evaporated faster than water. Acoustic cavitation of UAE during vibration also has the probability to cause the loss of light fraction of volatile compounds from dried turmeric material.

\section{Conclusion}

Ultrasonic assisted extraction (UAE) was able to produce worthy Curcuma longa L. extract in term of high percentage yield and high curcuminoids content. While supercritical fluid extraction (SFE) was also able to produce worthy Curcuma longa L. extract based on the volatile compounds present. Both techniques have been chosen as no toxic organic solvent involves in the extraction. In this regard, it can be concluded that a selection of extraction techniques to obtain turmeric extract is dependent on the proposed use of the extracts whether it is based on percentage yield of oleoresin, curcuminoids concentration or volatile compounds composition.

\section{Acknowledgement}

The authors would like to thank Universiti Teknologi MARA (UiTM) and the Ministry of Higher Education for technical support and Fundamental Research Grant Scheme (600-RMI/FRGS 5/3 (149/2013)) for funding this study.

\section{References}

1. Singh, S., Joshi, R. K. and Nayak, S. (2013). Identification of elite genotypes of turmeric through agroclimatic zone based evaluation of important drug yielding traits. Industrial Crops and Products, 43: $165-171$.

2. Braga, M. E. M., Leal, P. F., Carvalho, J. E. and Meireles, M. A. A. (2003). Comparison of yield, composition and antioxidant activity of turmeric (Curcuma longa L.) extracts obtained using various techniques. Journal of Agricultural \& Food Chemistry, 51: $6604-6611$.

3. Began, G., Goto, M., Kodama, A. and Hirose, T. (2000). Response surfaces of total oil yield of turmeric (Curcuma longa) in supercritical carbon dioxide. Food Research International, 33: 341 - 345.

4. Haiyee, Z. A., Saim, N., Said, M., Illias, R. M., Mustapha, W. A. W. and Hassan, O. (2009). Characterization of cyclodextrin complexes with turmeric oleoresin. Food Chemistry, 114: $459-465$.

5. Chang, L-H., Jong, T-T., Huang, H-S., Nien, Y-F. and Chang, C-M. J. (2006). Supercritical carbon dioxide extraction of turmeric oil from Curcuma longa Linn and purification of turmerones. Separation and Purification Technology, 47: 119-125.

6. Vinatoru, M. (2001). An overview of the ultrasonically assisted extraction of bioactive principles from herbs. Ultrasonics Sonochemistry, 8: $303-313$.

7. Daneshvand, B., Ara, K. M. and Raofie, F. (2012). Comparison of supercritical fluid extraction and ultrasoundassisted extraction of fatty acids from quince (Cydonia oblonga Miller) seed using response surface methodology and central composite design. Journal of Chromatography A, 1252: 1 - 7.

8. Wang, L. and Weller, C. L. (2006). Recent advances in extraction of nutraceuticals from plants. Trends in Food Science \& Technology, 17: 300 - 312.

9. Zaibunnisa, A. H., Norashikin, S., Mamot, S. and Osman. H. (2009). An experimental design approach for the extraction of volatile compounds from turmeric leaves (Curcuma domestica) using pressurised liquid extraction (PLE). LWT - Food Science and Technology, 42(1): 233 - 238.

10. Official Method of Analysis, AOAC $17^{\text {th }}$ edn. (2000). Moisture in Spices / I.S Specification No I.S 1797- 1985. Methods of Test for Spices and Condiments.

11. Zaibunnisa, A. H. (2009). Inclusion complexes of turmeric oleoresin with $\beta$ and $\gamma$-cyclodextrin. Ph.D. Thesis, Universiti Kebangsaan Malaysia. 
12. Gilda, S., Kanitkar, M., Bhonde, R. and Paradkar, A. (2010). Activity of water-soluble turmeric extract using hydrophilic excipients. LWT - Food Science and Technology, 43(1): 59-66.

13. Wakte, P. S., Sachin, B. S., Patil, A. A., Mohato, D. M., Band, T. H. and Shinde, D. B. (2011). Optimization of microwave, ultra-sonic and supercritical carbon dioxide assisted extraction techniques for curcumin from Curcuma longa. Separation and Purification Technology, 79: 50 - 55.

14. Li, S., Yuan, W., Deng, G., Wang, P., Yang, P. and Aggarwal, B. B. (2011). Chemical Composition and Product Quality Control of Turmeric (Curcuma longa L.). Pharmaceutical Crops, 2: 28 - 54.

15. Allawzi, M., Al-Otoom, A., Allaboun, H., Ajlouni, A. and Nseirat, F. A. (2011). $\mathrm{CO}_{2}$ supercritical fluid extraction of Jordanian oil shale utilizing different co-solvents. Fuel Processing Technology, 92(10): 2016 2023.

16. Herrero, M., Castro-Puyana, M., Mendiola, J. A. and Ibañez, E. (2013). Compressed fluids for the extraction of bioactive compounds. TrAC Trends in Analytical Chemistry, 43: 67 - 83.

17. Sovilj, M. N., Nikolovski, B. G. and Spasojević, M. Đ. (2011). Critical review of SFE of selected spice plant materials. Macedonian Journal of Chemistry and Chemical Engineering, 30(2): 197 - 220.

18. Singh, G., Singh, O. P. and Maurya, S. (2002). Chemical and biocidal investigations on essential oils of some Indian Curcuma species. Progress in Crystal Growth and Characterization of Materials, 45: 75 - 81.

19. Gounder, D. K. and Lingamallu, J. (2012). Comparison of chemical composition and antioxidant potential of volatile oil from fresh, dried and cured turmeric (Curcuma longa) rhizomes. Industrial Crops and Products, 38: $124-131$. 